\title{
2006 年度フォローアップ結果とエネルギー関連情報*
}

日本製紙連合会 稲 田治

\section{Results of the Fy 2006 Follow-up to JPA's Voluntary Action Plan and Report of Energy Situation in the Pulp and Paper Industry in Japan}

\author{
Osamu Inada \\ Japan Paper Association
}

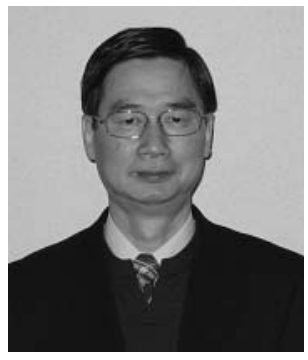

The Japan Paper Association (JPA) has been actively working to save energy since 1997 when it established its “Voluntary Action Plan on Environmental Issues”. JPA declared its policy of restraining $\mathrm{CO}_{2}$ emissions as one of the actions : (1) By Fy 2010, reduce fossil energy consumption per product unit for paper products by $13 \%$ from that of Fy 1990 level, $\mathrm{CO}_{2}$ emission per product unit for paper products by $10 \%$. (2) By 2010, the in-andoutside country afforestation area owned or managed expand to 600, 000 ha.

Since Fy 1990, JPA has been following through on the actual results of the unit of energy in the year, and has been publishing its results compared with that in Fy 1990. The following are the results for Fy 2005 and reports of energy situation in the pulp and paper industry in Japan.

The survey also reported on energy consumption, $\mathrm{CO}_{2}$ emissions and the position of the pulp and paper industry in Japan, and information related Laws.

分類 $: Z_{2}$ 紙パルプ産業環境一般, $\mathrm{X}_{2}$ 紙パルプ産業一般

\section{1.はじめに}

日本経団連加盟の各業界は, 温暖化防止に向け二酸化炭 素 $\left(\mathrm{CO}_{2}\right)$ 排出量を削減するために, 環境自主行動計画（温 暖化対策）を作成して 1997 年より取り組んでいる。日本 製紙連合会も活動開始当初から目標をたてて参加し, 1990 年度以降の化石エネルギーと $\mathrm{CO}_{2}$ 排出量の削減実績を毎 年調査し, その結果を公表している。ここでは 2005 年度 の実績について報告する。

また，日本におけるエネルギー消費量, $\mathrm{CO}_{2}$ 排出量およ びそれに占める紙パルプ産業の位置づけや, 関連法律情報 を提示した。

\section{2006 年度自主行動計画フォローアップ (2005 年度実績)}

日本製紙連合会の「環境に関する自主行動計画（温暖

\footnotetext{
*第 11 回省エネルギーセミナー講演
}

化)」の進渉状況を確認するため, 昨年 7 月, 2006 年度フ オローアップ調査（2005 年度実績）を実施した。今回の フォローアップは, 目標アップ後の 2 回目の調査である。 【日本製紙連合会 地球温暖化対策自主行動計画目標】

(1) 2010 年度までに製品当り化石エネルギー原単位を 1990 年度比 $13 \%$ 削減し, $\mathrm{CO}_{2}$ 排出原単位を $10 \%$ 削 減する。

(2) 2010 年までに所有または管理する国内外植林地面 積を 60 万 ha に拡大する。

\section{1 調 査項 目}

調査対象：正会員等 40 社（他事業の比重の高い 1 社を 除き，非会員の協力会社 3 社を含む）

回答：36 社 103 工場（回答 103 工場の 2005 年度に おける紙・板紙生産シェアは対象会社合計の $98.9 \%$ ，全製紙会社合計の $88.8 \%$ を占める)

調查年度 : 1990 年度 2005 年度（16 年間） 調査項目 :

(1) 工場別燃料 - 購入電力の消費量 
工場の全消費量（紙パルプ用途以外の消費も含む）。 ただし，販売電力の発電に相当する燃料消費量は控 除。

(2) 工場別の紙・板紙・パルプ生産量

(3) 2005 年度化石エネルギー原単位の改善 - 悪化理 由

(4) 2005 年度に実施した省エネルギー投資および然 料転換投資

(5) 今後の対策・計画 等

(6) 民生・運輸部門の調査

(7) 植林の進渉状況

\section{2 調 査結 果}

\subsubsection{0 年度〜2005 年度の進渉状況}

単年度ごとのデータを図 1 に, 3 点移動平均を図 2 に示 す。単年度ごとのデータは年度ごとの景気変動（生産量変 動）を反映して，原単位変動が大きいので，3 年平均の 3 点移動平均でみると傾向がわかる。

2005 年度の化石エネルギー原単位は, 省エネルギーお よび，化石エネルギーから再生可能エネルギーと廃棄物エ
ネルギーへの転換が昨年に引き続き進んだことから，3.3 pt 減と 2 年連続して大幅に改善された。また，1990年度 比では $86.5 \%$ となり，目標の $87 \%$ を若干上回った。

化石エネルギー起源 $\mathrm{CO}_{2}$ 排出原単位の改善は, 化石エ ネルギー原単位の改善に比べて遅れ気味であった。これは 当初，エネルギーセキュリティおよびコスト的にも有利で あったことから，重油から石炭への燃料転換が進んだこと による（図 3）。しかし，2003 年度以降は再生可能エネル ギーと廃棄物エネルギーへの転換が急激に進み（図 4), その結果 $\mathrm{CO}_{2}$ 排出原単位が改善された。

2005 年度の $\mathrm{CO}_{2}$ 排出原単位は前年度に比べ，3.9 pt 減 と化石エネルギー原単位同様に，2 年連続して大幅に改善 された。1990年度比でも $90.8 \%$ となり，目標の $90 \%$ に 近づた。

\subsubsection{5 年度実施の省エネルギー投資と 燃料転換投資}

\section{1）省エネルギー投資}

1997 年度以降の省エネルギー投資額と化石エネルギー 削減効果の推移を表 1 に示した。省エネルギー投資は, 2002

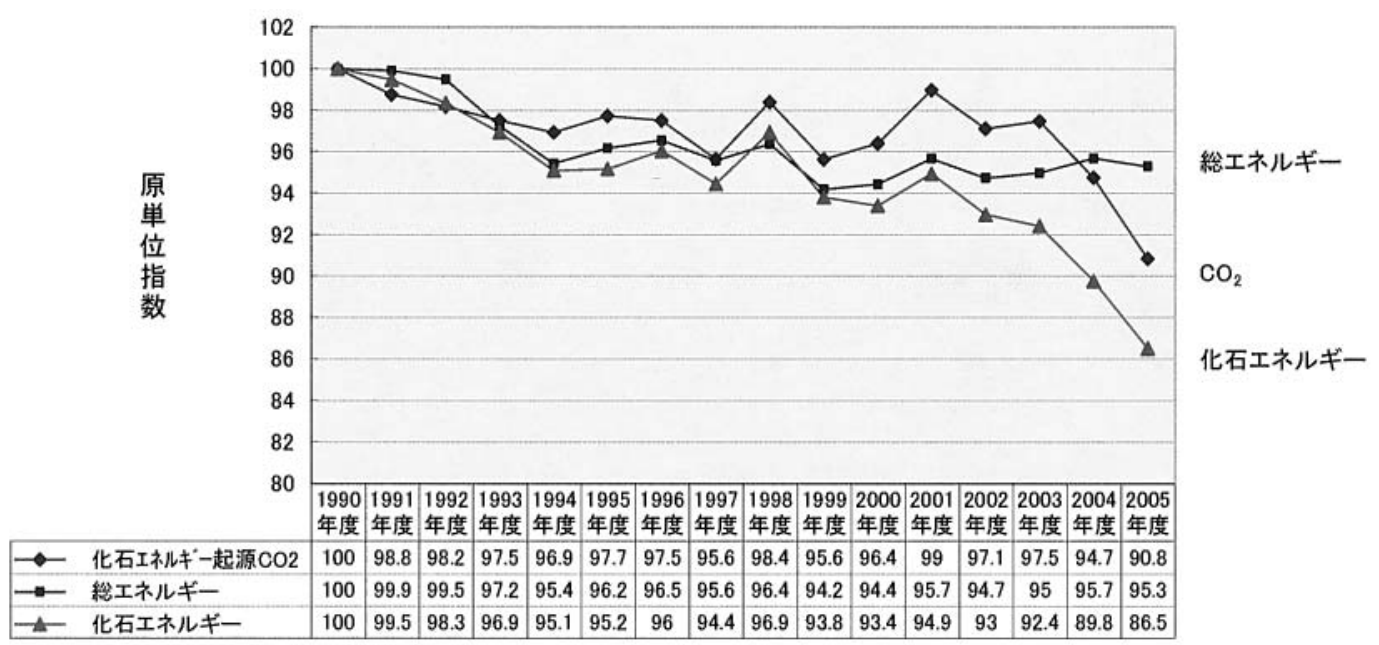

図 1 化石エネルギー原単位指数および $\mathrm{CO}_{2}$ 排出原単位指数の推移（1990 年度 $=100 ）$

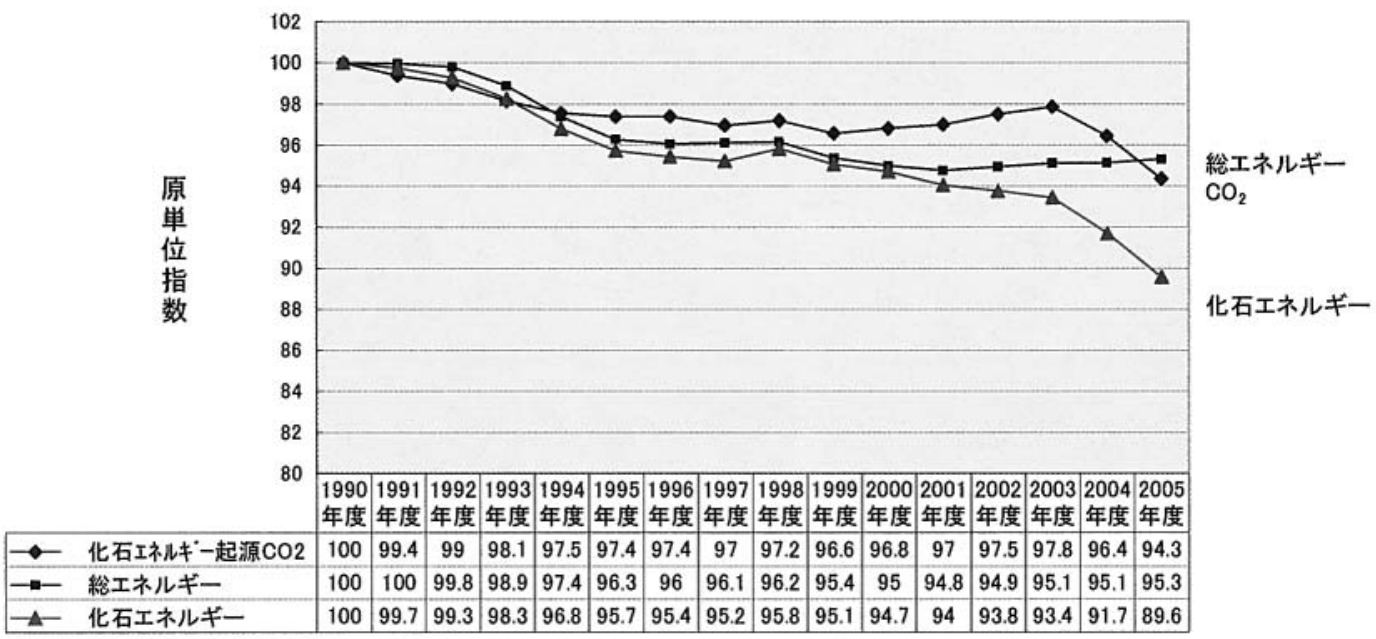

図 2 化石エネルギー原単位指数および化石エネルギー起源 $\mathrm{CO}_{2}$ 排出原単位指数の推移（3 点平均）（1990 年度=100） 
年度を底として徐々に増加して来たが，2005 年度はほぼ 2002 年度水準に戻った。なお， 2004 年度は動力部門で, 回収ボイラー更新のため大型投資（13,000 百万円， $\Delta 973$ $\mathrm{TJ} /$ 年）が実施されたが，これを除くと年間投資は 11,906 百万円であり，2002 年度から効率の良い投資が継続して いる。

\section{2）燃料転換投資}

化石エネルギーおよび化石エネルギー起源 $\mathrm{CO}_{2}$ 排出量 削減のため, 化石エネルギーから再生可能エネルギーと廃 裹物エネルギー, 或いは同じ化石エネルギーでも $\mathrm{CO}_{2}$ 排
出係数の小さい都市ガスや天然ガスへの燃料転換投資 が，2002 年度以降大幅に増加している（表 2)。

\subsection{3 化石エネルギー起源 $\mathrm{CO}_{2}$ 排出量の増減に 関する要因分析}

化石エネルギー起源 $\mathrm{CO}_{2}$ 排出量は，生産量増加による 寄与分が 1990 年度に比べて 2,183 千 t $(8.6 \%)$ あったも のの，製紙業界の努力で 2,576 千 $\mathrm{t}(\boldsymbol{\Delta} 10.1 \%)$ 削減した 結果，電力業界の $\mathrm{CO}_{2}$ 排出係数悪化分 48 千 $\mathrm{t}(0.2 \%)$ を 加味しても， $\mathrm{CO}_{2}$ 排出量は 345 千 $\mathrm{t}(\boldsymbol{\Delta} 1.4 \%)$ 減少し，1990 年度を初めて下回った（表 3）。

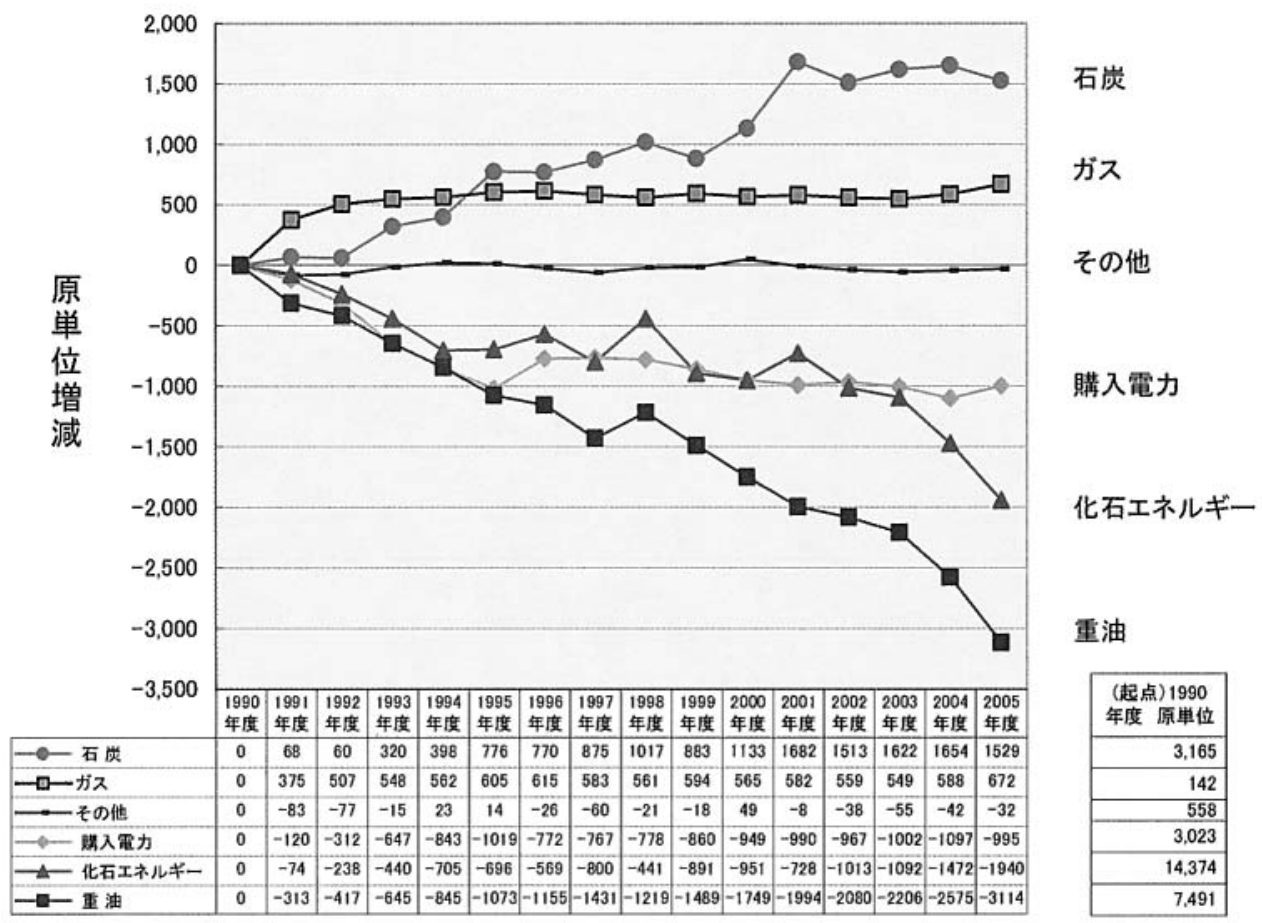

図 3 化石エネルギー燃料別原単位の推移（MJ/t，1990 年度基準）

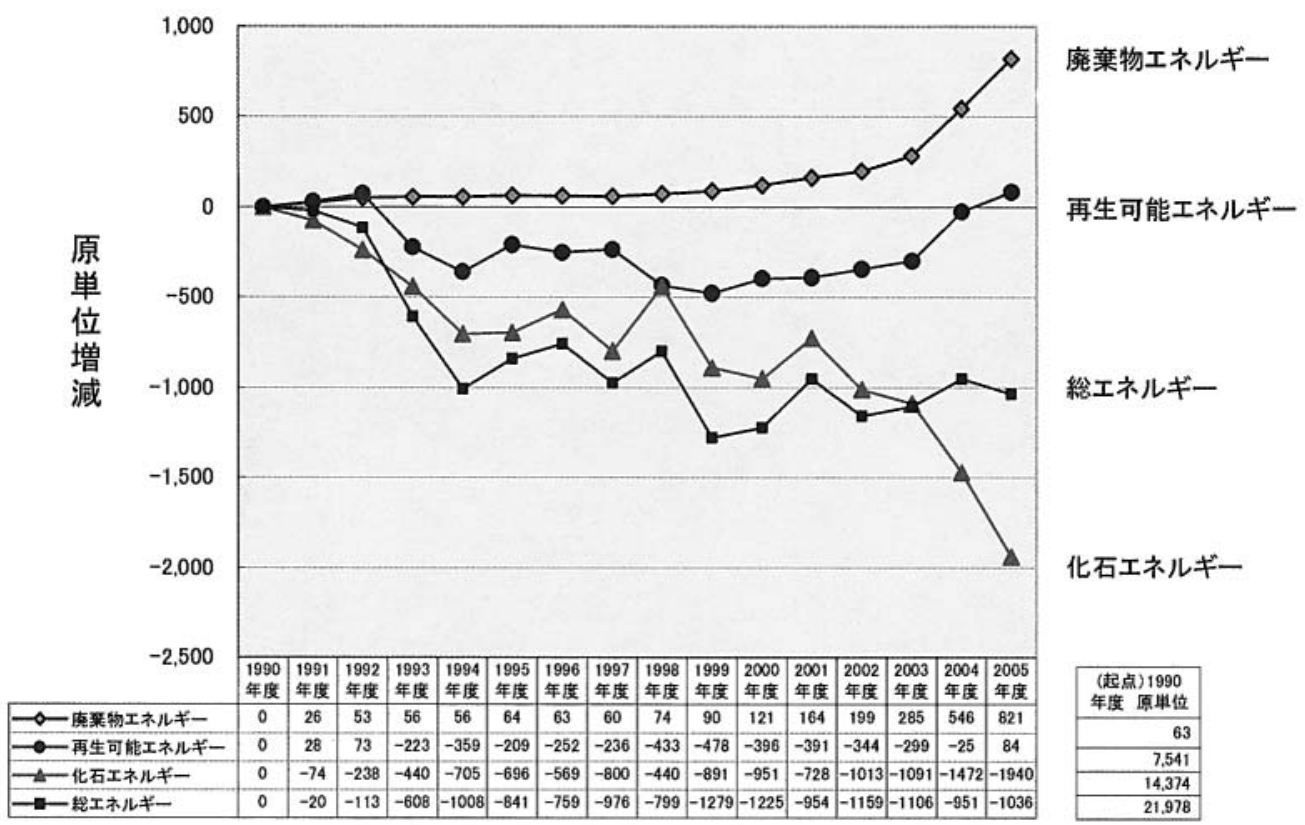

図 4 エネルギー分類別原単位の推移（MJ/t，1990 年度基準） 
表 1 部門別省エネルギー投資額・効果の推移

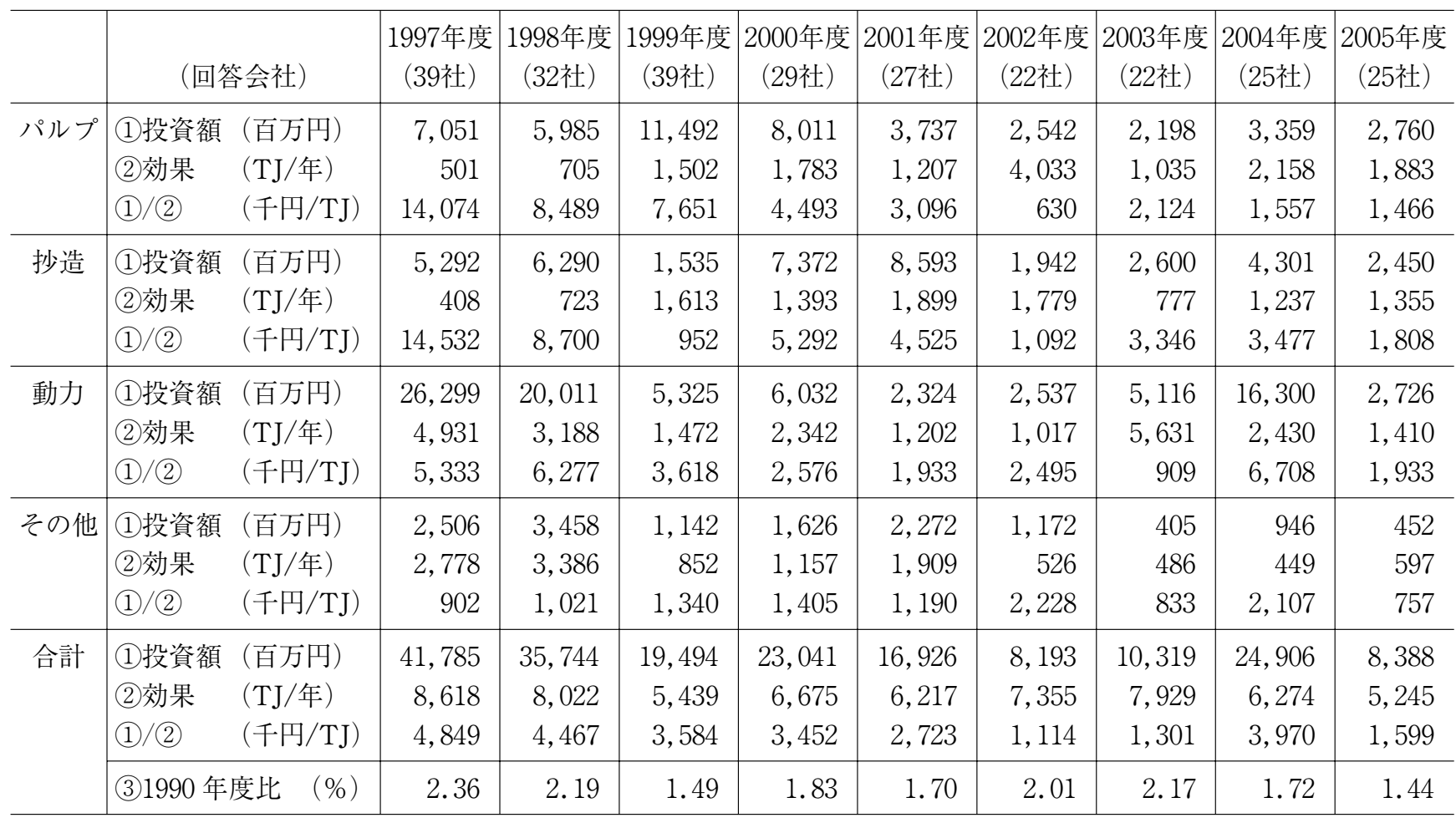

注）（31990 年度比（\%）：1990 年度の化石エネルギー使用量 365,458 TJに対するその年の投資省エネ効果量（TJ）の 割合

表 2 燃料転換投資の推移

\begin{tabular}{ll|r|r|r|r|r|r}
\hline & & 2000 年度 & 2001年度 & 2002年度 & 2003年度 & 2004年度 & 2005年度 \\
\hline 投資額 & (百万円) & 24 & 0 & 6,650 & 7,826 & 18,412 & 17,714 \\
\hline 化石エネルギー削減量 & ( $\mathrm{TJ} /$ 年) & 151 & 0 & 908 & 3,878 & 9,046 & 13,428 \\
\hline 化石エネルギー起源 $\mathrm{CO}_{2}$ 削減 & (千 $\mathrm{t} /$ 年) & 3 & 0 & 43 & 258 & 494 & 1,016 \\
\hline
\end{tabular}

表 32005 年度化石エネルギー起源 $\mathrm{CO}_{2}$ 排出量の増減量と割合（対 1990 年度）

\begin{tabular}{|c|c|c|c|c|c|c|}
\hline & \multicolumn{2}{|c|}{ 2005年度要因分析 } & \multicolumn{2}{|c|}{$\begin{array}{l}\text { (参 1) 電力係数の) } \\
\text { 影響を控除 }\end{array}$} & \multicolumn{2}{|c|}{$\begin{array}{c}\text { (参 2) 原発停止の } \\
\text { 影響を控除 }\end{array}$} \\
\hline & $\begin{array}{c}\mathrm{CO}_{2} \text { 排出量 } \\
(\text { 千 } \mathrm{t})\end{array}$ & $\begin{array}{c}\text { 対90年度 } \\
(\%)\end{array}$ & $\begin{array}{c}\mathrm{CO}_{2} \text { 排出量 } \\
(千 \mathrm{t})\end{array}$ & $\begin{array}{c}\text { 対90年度 } \\
(\%)\end{array}$ & $\begin{array}{c}\mathrm{CO}_{2} \text { 排出量 } \\
(\text { 千 } \mathrm{t})\end{array}$ & $\begin{array}{c}\text { 対90年度 } \\
(\%)\end{array}$ \\
\hline 1990 年度 化石エネルギー起源 $\mathrm{CO}_{2}$ 排出量 & 25,419 & & 25,419 & & 25,419 & \\
\hline 2005 年度 化石エネルギー起源 $\mathrm{CO}_{2}$ 排出量 & 25,074 & & 25,026 & & 24,752 & \\
\hline 化石エネルギー起源 $\mathrm{CO}_{2}$ 排出量の増減 & $\mathbf{\Delta} 345$ & $\mathbf{\Delta} 1.4$ & $\mathbf{A} 393$ & $\mathbf{\Delta} 1.5$ & $\mathbf{\Delta} 667$ & $\mathbf{\Delta} 2.6$ \\
\hline （内訳）製紙業界の努力 & $\mathbf{\Delta} 2,576$ & $\Delta 10.1$ & $\mathbf{\Delta} 2,576$ & $\Delta 10.1$ & $\mathbf{\Delta} 2,576$ & $\Delta 10.1$ \\
\hline 電力業界の寄与 & 48 & 0.2 & - & - & $\mathbf{\Delta} 274$ & $\mathbf{\Delta} 1.1$ \\
\hline 生産活動の寄与 & 2,183 & 8.6 & 2,183 & 8.6 & 2,183 & 8.6 \\
\hline
\end{tabular}

(参 1) 電力の $\mathrm{CO}_{2}$ 排出係数の影響を控除すると排出量は $\mathbf{\Delta} 393$ 千 $\mathrm{t}-\mathrm{CO}_{2}$ となる。(1990 年度の排出係数 1.019 使用)

(参 2) 原発停止がなく, 2000 年度並みの原発稼動率であれば排出量は $\mathbf{\Delta} 667$ 千 $\mathrm{t}-\mathrm{CO}_{2}$ となる。（2000年度の排出係数 0.920 使用) 


\subsection{4 今後実施予定の対策}

1）今後の投資計画

省エネルギー投資は毎年行う汎用投資（2 億円未満）と 大型投資 (2010 年度までに稼動する 2 億円以上の長期計 画投資）とにわけて集計した。省エネルギー汎用投資につ いては，過去の実績平均（2000～2005 年度）と同じ規模 の投資が 2006 年度以降も続くものとして試算した。また, 燃料転換は 2010 年度までに稼動する投資による化石エネ ルギー削減量を集計した（表 4）。

また，今後の燃料転換設備投資計画による再生可能エネ ルギーおよび廃棄物エネルギーの使用量増加と, 2010 年 度使用量は表 5 のとおりである。

2) 2010 年度試算

今後の投資計画（表 4）および転換燃料使用計画（表 5) をベースに，毎年恒常的におこなわれる環境対策，品質対 策，要員合理化対策などの増エネルギーについての実績を 勘案し，燃料転換に際しての燃料調達率も織込んで試算し た。その結果，表 6 に示したように，省エネルギー+燃料 転換後の化石エネルギー原単位は $81.9 \%$ となり，目標の $87 \%$ を達成できる。また， $\mathrm{CO}_{2}$ 排出原単位も $85.4 \%$ で目 標 $90.0 \%$ を達成できる。また，2010 年度の生産量が 1990 年度比約 $10 \%$ 増加しているのに対して，化石エネルギー 消費量は $90.2 \%$ であり, $\mathrm{CO}_{2}$ 排出量も $94.1 \%$ といずれも 1990 年度を下回っている。

ただし，今後の景気動向により投資が抑制されたり，転
換燃料の量に限りがあるため調達率が低下したり，あるい は燃料転換に伴う焼却灰の処理問題など不安定要因が多々 あるため，試算数字は悪化することがあり得る。

\section{3 植林の推進}

植林について当初計画は「植林は紙パルプ原料確保の観 点のみならず $\mathrm{CO}_{2}$ の吸収固定，炭素の循環利用の推進の 点からも重要であり，国内外における植林事業の推進に努 め，2010 年までに所有又は管理する植林地の 55 万 ha の拡大を目指す」としていたが，昨年度の計画見直しに際 し，これを強化し，目標を 60 万 ha に拡大した。

植林面積の推移は順調であり，2005 年度末で国内外合 わせて，536千 ha となっており，1990 年度に対して 261 千 ha 増加, 目標值 600 千 ha の $89 \%$ に達している（表 7)。 海外植林は，2005 年度末で，1990 年度に対して 257 千 ha 増加（東京都 23 区の 4.2 倍）の 386 千 ha である。地域 はブラジル，オーストラリア，チリ，ニュージーランド， ベトナム，南アフリカ，エクアドル，中国，ラオスの 9 ケ 国である。

\section{<参考・古紙利用率の推移 $>$}

参考のため，古紙利用率の推移を図 5 に示した。

\section{4 他業界との比較}

日本経団連のホームページから入手した 2006 年度フォ ローアップの結果を基に作成した表を以下に示した（表 8)。 http://www.keidanren.or.jp/japanese/policy/2006/089 index.html

表 4 今後の投資計画（2006 年〜2010 年度累計）

\begin{tabular}{cr|r|r}
\hline & $\begin{array}{c}\text { 投資子定額 } \\
\text { (百万円) }\end{array}$ & $\begin{array}{r}\text { 化石エネルギー削減量 } \\
(\mathrm{TJ})\end{array}$ \\
\hline 省エネルギー投資 汎用投資 & 24,247 & 27,225 \\
" & 大型投資 & 49,114 & 8,060 \\
燃料転換投資 & & 147,217 & 36,330 \\
\hline \multicolumn{2}{c|}{ 合計 } & 220,578 & 71,615 \\
\hline
\end{tabular}

表 5 燃料転換設備投資計画によるバイオマス燃料，廃棄物燃料 2010 年度使用量

\begin{tabular}{|c|c|c|c|c|c|c|}
\hline & \multicolumn{2}{|c|}{ 2005年度＼cjkstart実績 } & \multicolumn{2}{|c|}{ 2006～2010年度 増加 } & \multicolumn{2}{|c|}{ 2010年度＼cjkstart使用量 } \\
\hline & (BD t/年) & ( $\mathrm{TJ} /$ 年) & （BD t/年） & （TJ/年） & （BD t/年） & ( $\mathrm{TJ} /$ 年) \\
\hline 廃材，バーク & 876,409 & 14,671 & $1,057,997$ & 17,468 & $1,934,406$ & 32,139 \\
\hline PS, 紙屑 & $1,285,534$ & 13,776 & 116,271 & 849 & $1,401,805$ & 14,625 \\
\hline $\mathrm{RDF}+\mathrm{RPF}$ & 465,486 & 10,780 & 190,636 & 4,645 & 656,122 & 15,425 \\
\hline 廃プラスチック & 38,487 & 1,156 & 166,667 & 5,243 & 205,154 & 6,400 \\
\hline 廃タイヤ & 251,361 & 8,266 & 246,652 & 7,987 & 498,012 & 16,253 \\
\hline 廃油 & 68,112 & 2,738 & 15,016 & 469 & 83,128 & 3,207 \\
\hline メタン & 258 & 10 & 1,712 & 63 & 1,970 & 73 \\
\hline
\end{tabular}

注）廃油の単位は $\mathrm{k} l$ ，メタンは千 $\mathrm{Nm}^{3}$ である 
表 6 2010年度試算

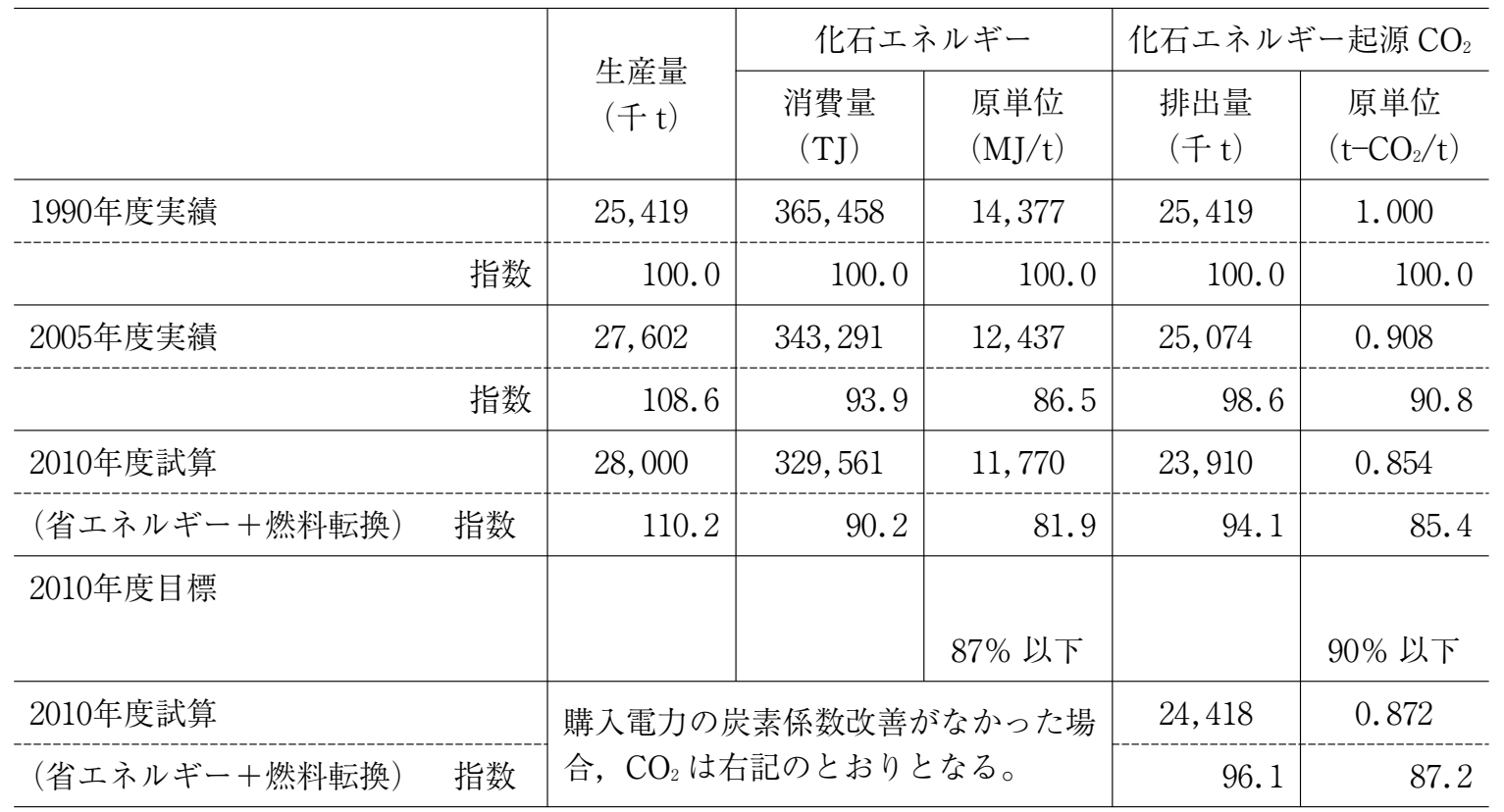

表 7 植林面積の推移

\begin{tabular}{c|c|c|c|c|c|c|c|c}
\hline & 1990年度 & 1995年度 & 2000年度 & 2001年度 & 2002年度 & 2003年度 & 2004年度 & 2005年度 \\
\hline 国内 & 146 & 144 & 128 & 125 & 121 & 139 & 151 & 150 \\
\hline 海外 & 129 & 178 & 278 & 301 & 342 & 353 & 355 & 386 \\
\hline 合計 & 275 & 322 & 406 & 426 & 463 & 492 & 506 & 536 \\
\hline 対目標 $(\%)$ & 46 & 54 & 68 & 71 & 77 & 82 & 84 & 89 \\
\hline
\end{tabular}

注） 2003 年度以降の国内は関連会社分を含む
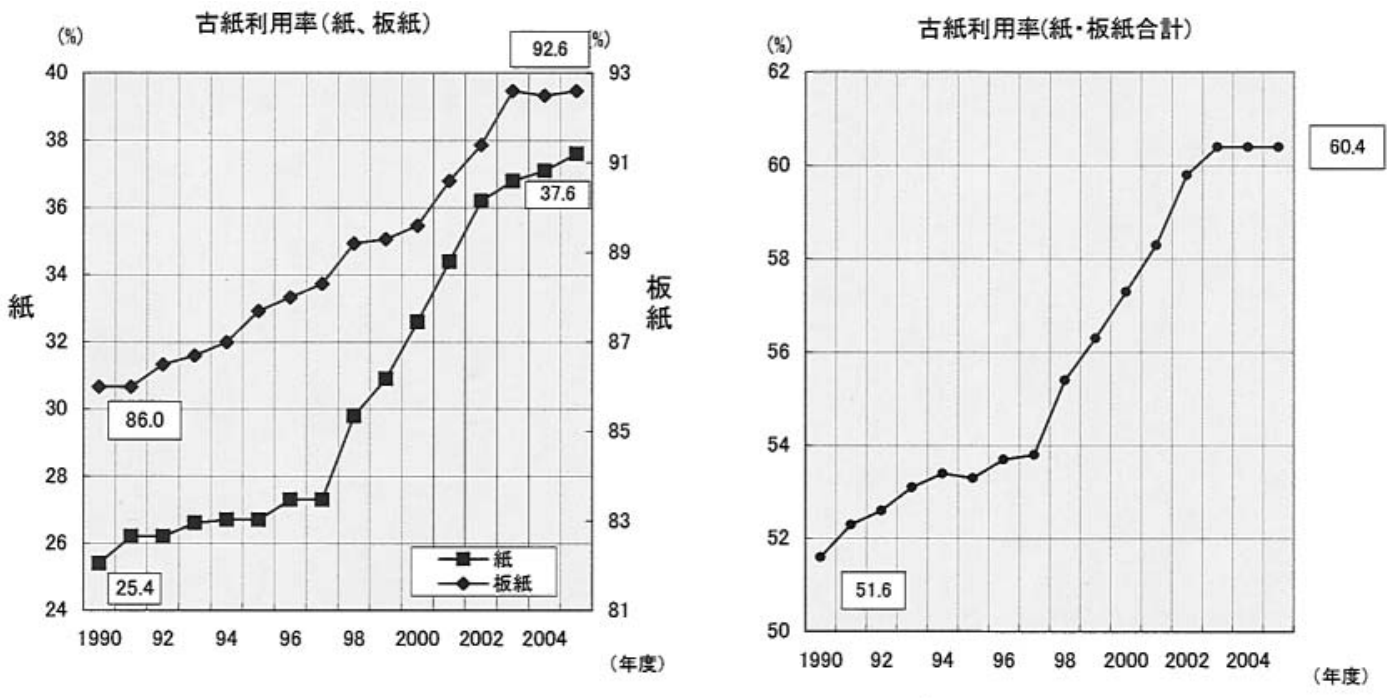

资料:経済産菜省「紙・印刷・ブラステクク・ゴム梨品統計年報」2005年度暫定

図 5 古紙利用率の推移 
表 $8 \mathrm{CO}_{2}$ 排出量に関する業種別動向（日本経団連 $\mathrm{HP}$ より）

\begin{tabular}{|c|c|c|c|c|c|c|c|c|}
\hline 業 種 & 1990年度 & 2004年度 & \multicolumn{2}{|c|}{ 2005年度 } & 199 & 年度比 & \multicolumn{2}{|c|}{ 前年度比 } \\
\hline 電気事業連合会 & 27,700 & 36,400 & & 37,500 & & $35.4 \%$ & & $3.0 \%$ \\
\hline $\begin{array}{l}\text { 固有分：合計值に } \\
\text { はこちらを使用 }\end{array}$ & 3,100 & 3,850 & (4) & 3,880 & ( 8 ) & $25.2 \%$ & (18) & $0.8 \%$ \\
\hline 日本鉄鋼連盟 & 19,533 & 18,365 & ( 1 ) & 18,195 & (20) & $-6.9 \%$ & (23) & $-0.9 \%$ \\
\hline 日本化学工業協会 & 6,832 & 7,569 & $(2)$ & 7,516 & (12) & $10.0 \%$ & $(22)$ & $-0.7 \%$ \\
\hline 石油連盟 & 3,303 & 4,354 & ( 3$)$ & 4,479 & ( 2) & $35.6 \%$ & (13) & $2.9 \%$ \\
\hline 日本製紙連合会 & 2,542 & 2,586 & ( 5$)$ & 2,507 & (19) & $-1.4 \%$ & (32) & $-3.0 \%$ \\
\hline セメント協会 & 2,743 & 2,108 & ( 6$)$ & 2,178 & (27) & $-20.6 \%$ & (12) & $3.3 \%$ \\
\hline 電気·電子 4 団体 & 1,181 & 1,819 & ( 7 ) & 1,866 & ( 3$)$ & $58.0 \%$ & (15) & $2.6 \%$ \\
\hline 経団連合計 & 50,817 & 50,322 & & 50,507 & & $-0.6 \%$ & & $0.3 \%$ \\
\hline
\end{tabular}

（）は35 業種で排出量等の数值が大きい順。したがって年度比は（）が大きい方がよい。

2006 年度フォローアップには, 35 業種が参加した。2005 年度の $\mathrm{CO}_{2}$ 排出量は 5 億 507 万 $\mathrm{t}-\mathrm{CO}_{2}$ となり, 前年度比 で $0.3 \%$ 増加, 1990 年度比で $0.6 \%$ 減少し， 6 年連続で目 標をクリアした。

$\mathrm{CO}_{2}$ 排出量が最も多かったのは鉄鋼業界, 続いて化学工 業界，石油業界，電力業界，製紙業界の順であり，製紙業 界は 5 位（製造業としては 4 位）でエネルギー多消費産業
であることがわかる。この順位は前年と変わらないが，製 紙業界として初めて 1990 年度を $\Delta 1.4 \%$ 下回った。

\section{3. エネルギー関連情報}

3.1 わが国のエネルギーバランス 2004 (平成 16) 年度 わが国エネルギーバランス 2004（平成 16）年度を図 6 に示した。

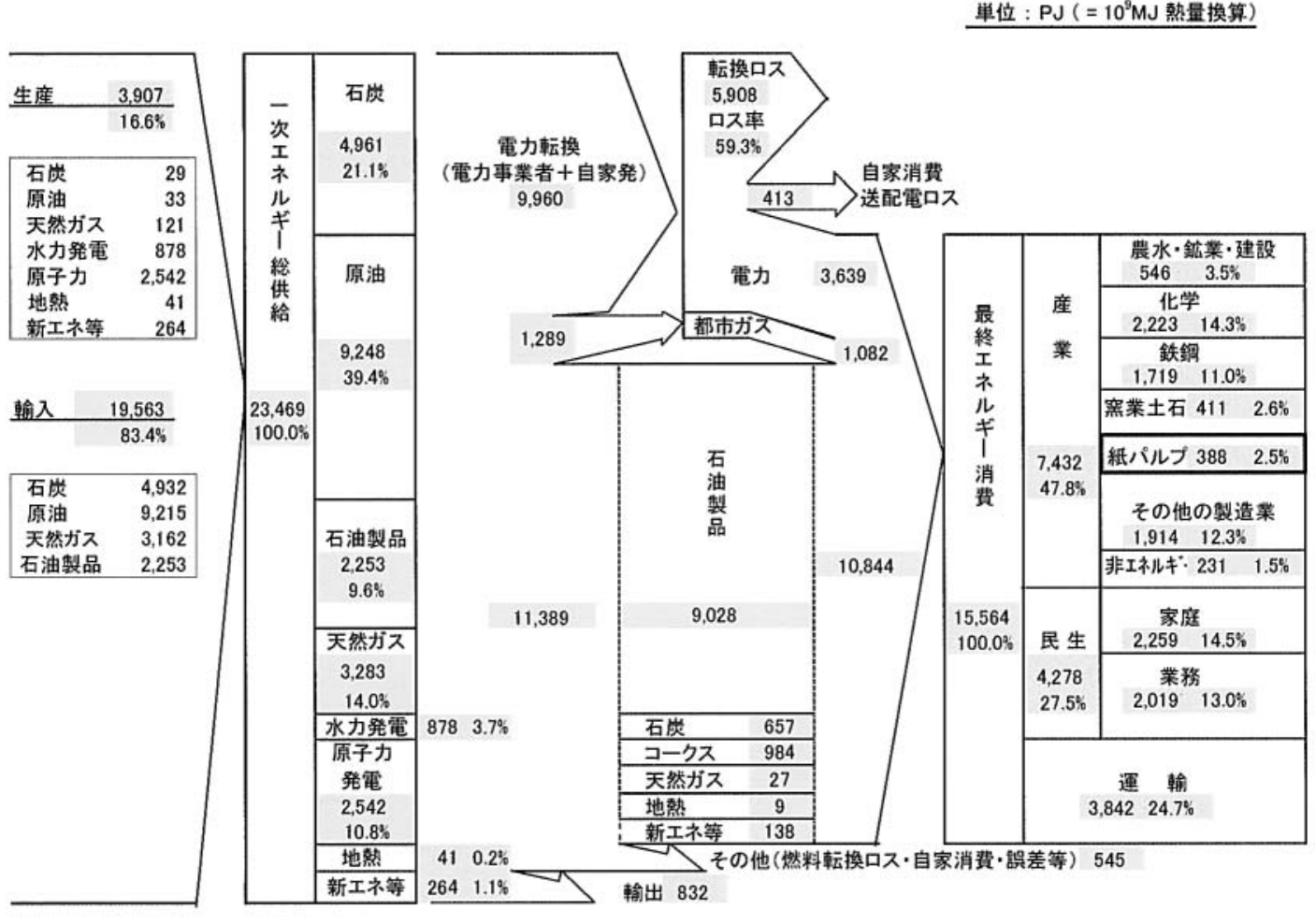

资料：「エネルギー・経済統計要覧2006」（（財）省エネルギーセンター）

図 6 わが国のエネルギー消費バランス 2004（平成 16）年度 

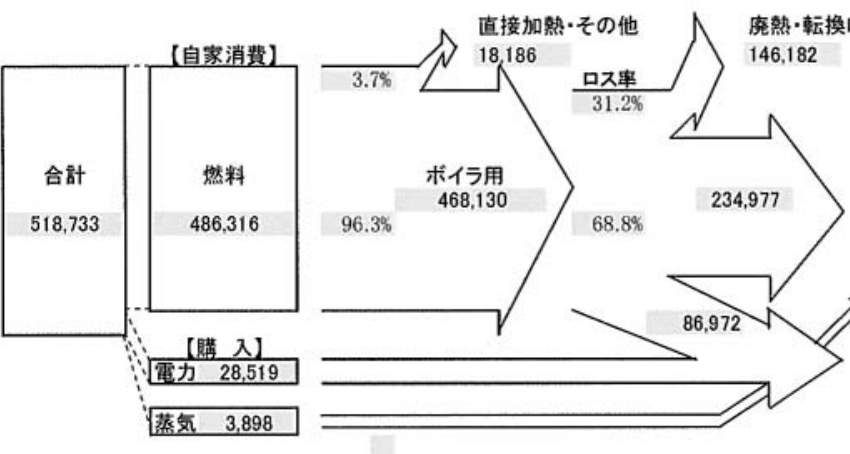

*電力は3.6MJ $/ \mathrm{kWh}(860 \mathrm{kcal} / \mathrm{kWh})$ で椋算
単位: $\mathrm{TJ}\left(=10^{6} \mathrm{MJ}\right.$ 熱量換算)

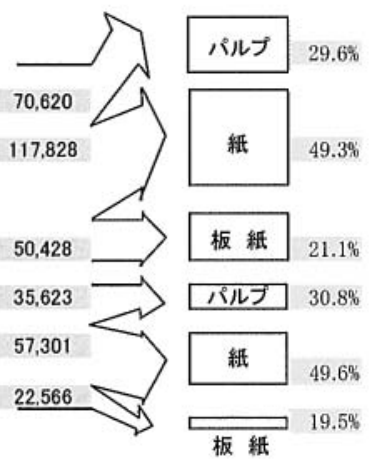

資料：「石油等消费動態较针年報」 2005 (平成17) 年

図 7 紙・パルプ産業のエネルギー消費バランス２005（平成 17）

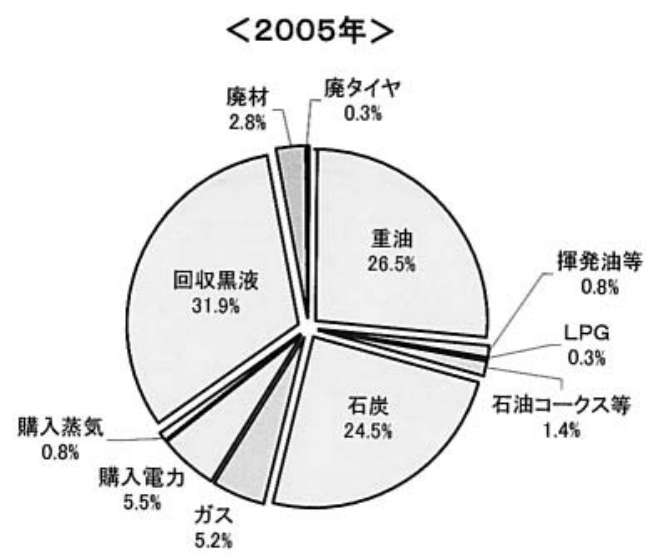

紙パルプ産業のエネルギー構成

\begin{tabular}{|c|c|c|}
\hline & 百万MJ & $\%$ \\
\hline 重油 & 137,574 & 26.5 \\
\hline 揮発油·灯油·軽油 & 4,382 & 0.8 \\
\hline LPG & 1.497 & 0.3 \\
\hline 石油コークス & 7.157 & 1.4 \\
\hline 石油系㞺料 & 150,609 & 29.0 \\
\hline 石炭 & 126,963 & 24.5 \\
\hline 都市ガス・天然ガス & 26,992 & 5.2 \\
\hline その他燃料 & 153,955 & 29.7 \\
\hline 購入電力 $(3.60 \mathrm{MJ} / \mathrm{kwh})$ & 28,519 & 5.5 \\
\hline 購入蒸気 & 3.898 & 0.8 \\
\hline 二次エネルギー & 32,417 & 6.2 \\
\hline 回収黒液 & 165.252 & 31.9 \\
\hline 廃材 & 14.735 & 2.8 \\
\hline 廃タイヤ & 1,765 & 0.3 \\
\hline 再生可能·㡾棄物エネルギー計 & 181,753 & 35.0 \\
\hline 合 計 & 518,733 & 100.0 \\
\hline
\end{tabular}

図 8 紙パルプ産業のエネルギー種類別消費量および構成比（2005 年）

\section{2 紙・パルプ産業のエネルギー消費バランス}

\section{5 (平成 17) 年}

紙・パルプ産業のエネルギー消費バランス 2004（平成

17）年を図 7 に示した。

\section{3 エネルギー種類別消費量及び構成比の推移}

$\mathrm{KP}$ 工場のパルプ廃液（黒液）と廃材による再生可能工 ネルギーが総エネルギーの 3 割強を占めており，このバイ オマス比率の突出が製紙業界の特徵である（図 8)。なお, 購入電力量は $3.6 \mathrm{MJ} / \mathrm{kWh}(860 \mathrm{kcal} / \mathrm{kWh})$ にて計算した。 オイルショック後，化石エネルギー原単位の改善が順調 な中，エネルギーセキュリテイから重油比率の引き下げが 求められ，製紙業界でも重油と石炭の価格差もあって，割 安な石炭への然料転換が進んできたため（図 9), $\mathrm{CO}_{2}$ 排 出原単位の改善が遅れ気味となった。しかし，2003 年度 以降は再生可能エネルギーや廃裹物エネルギーへの燃料転 換が各社によって急激に進められ，その結果 $\mathrm{CO}_{2}$ 排出原 単位の改善が進み，2005 年度もその効果が大いに出た。

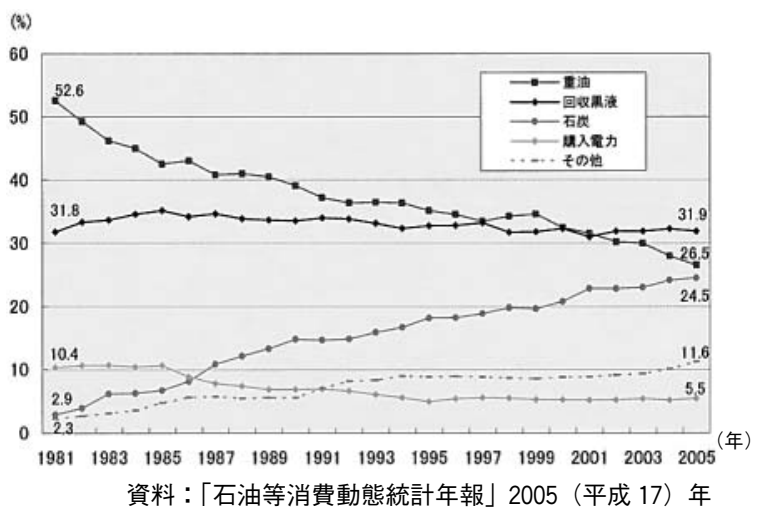

図 9 紙・パルプ産業のエネルギー種類別構成比の 推移（熱量ベース） 


\section{4 電力消費及び自家発電の状況}

紙・パルプ産業の電力消費量は製造業の中で第 3 位であ る（図 10）。パルプ化工程（蒸解，晒，黒液濃縮）や抄紙 工程（乾燥）で多量の中低圧蒸気を使用することから，ボ イラーで得られる高温高圧蒸気をまず発電に利用し，その 後の中低圧蒸気を熱利用するコジェネレーション（熱電併 給システム）が発達している。このように, 紙・パルプ産 業は構造的に自家発メリットがあるため, 1985 年からの 円高のメリットにより自家発が進み（図 11），その比率は, 製造業の中で実質的には最高水準の $75 \%$ に達している(製 造業第 2 位)。

\section{5 紙・板紙生産金額に占める主要化石エネルギー コストの推移}

1985 年からの円高の進行で急激に化石エネルギーコス 卜比率が低下したが, その後, 為替と生産量の変動により 多少の変化があるものの, 全体的には安定している（図 12, 表 9)。ただし，C重油価格は 2004 年央より急上昇し ており，それに引きずられる形で石炭の価格も上昇に転じ ている。今後の推移に注意を要する。

\section{6 わが国の二酸化炭素排出量}

2005 年度のわが国の $\mathrm{CO}_{2}$ 排出量は 12 億 9,670 万 $\mathrm{t}$ (速 報値）で, 1990 年度比 $13.3 \%$ （15, 300 万 $\mathrm{t}$ ）増加, 前年 度比 $0.8 \%(1,110$ 万 $\mathrm{t})$ 増加という結果となった（図 13）。

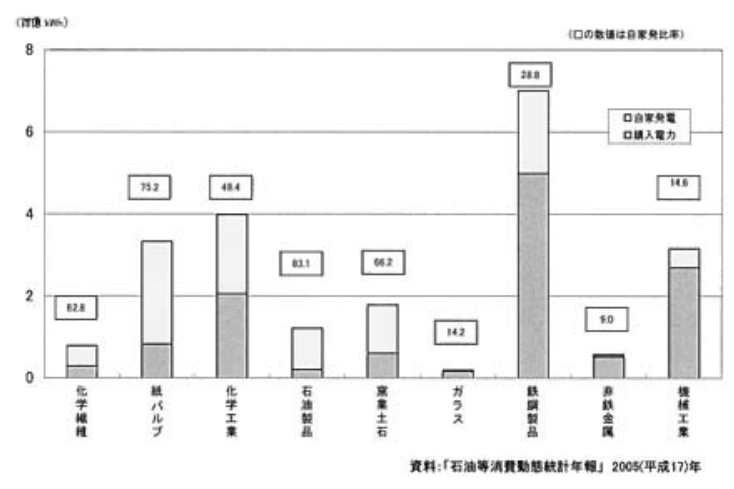

図 10 電力消費量 - 自家発電比率の産業間比較 2005 (平成 17）年

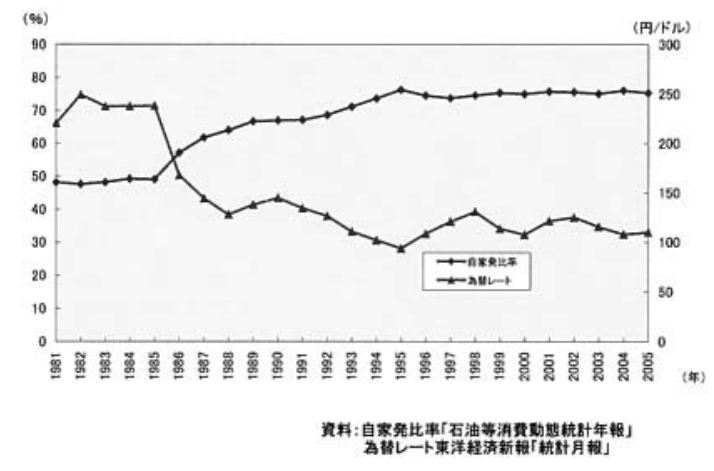

図 11 為替レートと自家発電比率の推移
部門別に見ると, 産業部門からの排出は, 前年度比 $0.2 \%$ （70 万 t）増加したが，1990 年度比では $3.2 \% （ 1,600$ 万 t) 減少となっている。家庭部門は厳冬により使用電気量が増 加したため, 前年度比 4.5\%（700万t）増加し，1990 年 度比でも $37.4 \%(4,800$ 万 t） の増加となっている。一方, 運輸部門は自家用自動車の排出量が前年度比 $3.9 \%(390$ 万 t）減少し，部門全体でも $1.8 \% （ 480$ 万）減少した が，1990 年度比では $18.1 \%(4,000$ 万 t ）の増加となって いる。

また，業務その他部門（商業，オフィス，銀行等）は家 庭部門と同様に厳冬による使用電力が増加したため前年度 比 3.1\%（710 万 t）増加し，1990 年度比でも $42.2 \%(7,000$ 万 t）増加した。

部門別 $\mathrm{CO}_{2}$ 排出量の推移を表 10 に, 部門別 $\mathrm{CO}_{2}$ 排出量 内訳および排出量指数推移を図 14 に示す。

なお，これらの詳細版は日本製紙連合会のホームページ に公表しているのでご参照願う。

・紙・パルプ産業のエネルギー事情（2005 年度版）

http://www.jpa.gr.jp/ja/about/happyou/data/ kami_pulp.pdf

- 第 9 回（2006 年度）自主行動計画（温暖化）フォロ ーアップ結果

http://www.jpa.gr.jp/ja/about/happyou/data/follow_0609.pdf

\section{4. 関連法律情報}

\section{1 改正省エネルギー法}

地球温暖化防止に関する京都議定書の発効, 昨今の世界 的エネルギー需給の逼迫等, 最近のエネルギーを巡る諸情 勢を踏まえ, 各分野におけるエネルギー使用の合理化を一 層進めるため, 改正省エネルギー法が 2006 年 4 月に施行 された。ここでは関連の深い(1)工場・事業所に係る措置と, (2)荷主に係る措置について簡単に紹介する。

(1) 工場・事業所に係る措置

熱と電気を合算した年度使用量が原油換算で一定以上 （第 1 種 $3,000 \mathrm{k} l$, 第 2 種 $1,500 \mathrm{k} l$ ) の工場・事業所 をエネルギー管理指定工場として指定した。第 1 種エネ ルギー管理指定工場・事業所は, エネルギー使用量と, エネルギー使用に伴い発生する $\mathrm{CO}_{2}$ 量を定期的に報告

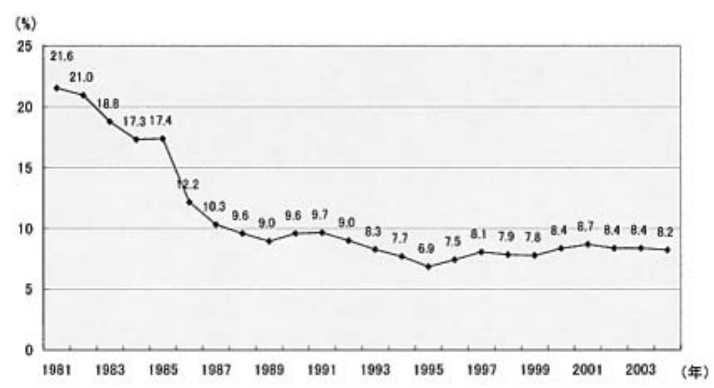

図 12 紙・板紙生産金額に占める主要化石 エネルギーコスト比率推移 
表 9 主要化石エネルギーコストの推移

\begin{tabular}{|c|c|c|c|c|c|c|c|c|c|c|c|c|c|c|c|}
\hline & \multicolumn{4}{|c|}{ 重油 } & \multicolumn{4}{|c|}{ 石炭 } & \multicolumn{4}{|c|}{ 購入電力 } & \multirow{3}{*}{$\begin{array}{c}\text { 主要エネ } \\
\text { ルギー費 } \\
\text { (a) } \\
\text { (億円) }\end{array}$} & \multirow{3}{*}{$\begin{array}{c}\text { 紙・板紙 } \\
\text { 生産額 } \\
(\mathrm{b}) \\
\text { (億円) }\end{array}$} & \multirow{3}{*}{$\begin{array}{l}\mathrm{a} / \mathrm{b} \\
(\%)\end{array}$} \\
\hline & \multirow{2}{*}{$\begin{array}{l}\text { 消費 } \\
千 \mathrm{k} l\end{array}$} & \multicolumn{2}{|c|}{ 単価 } & \multirow{2}{*}{$\begin{array}{l}\text { 金額 } \\
\text { 億円 }\end{array}$} & \multirow{2}{*}{$\begin{array}{c}\text { 消費 } \\
\text { 千 t }\end{array}$} & \multicolumn{2}{|c|}{ 単価 } & \multirow{2}{*}{$\begin{array}{l}\text { 金額 } \\
\text { 億円 }\end{array}$} & \multirow{2}{*}{$\begin{array}{c}\text { 消費 } \\
\text { 億 } \mathrm{kWh}\end{array}$} & \multicolumn{2}{|c|}{ 単価 } & \multirow{2}{*}{$\begin{array}{l}\text { 金額 } \\
\text { 億円 }\end{array}$} & & & \\
\hline & & 千円 $/ \mathrm{k} l$ & 円/GJ & & & 千円/t & 円/GJ & & & 円 $/ \mathrm{kWh}$ & 円/GJ & & & & \\
\hline 1981 & 4,945 & 56.1 & 1,368 & 2,775 & 453 & 17.7 & 695 & 80 & 113 & 21.5 & 2,278 & 2,433 & 5,288 & 24,531 & 21.5 \\
\hline 82 & 4,586 & 58.2 & 1,417 & 2,667 & 602 & 18.4 & 725 & 111 & 115 & 21.8 & 2,313 & 2,503 & 5,280 & 25,183 & 21.0 \\
\hline 83 & 4,352 & 51.3 & 1,251 & 2,233 & 958 & 16.3 & 640 & 156 & 116 & 21.8 & 2,313 & 2,534 & 4,923 & 26,192 & 18.8 \\
\hline 84 & 4,361 & 47.7 & 1,163 & 2,081 & 1,001 & 14.7 & 580 & 148 & 117 & 21.7 & 2,309 & 2,537 & 4,766 & 27,518 & 17.3 \\
\hline 85 & 4,147 & 49.6 & 1,209 & 2,057 & 1,076 & 13.4 & 527 & 144 & 120 & 21.9 & 2,329 & 2,632 & 4,833 & 27,796 & 17.4 \\
\hline 86 & 4, 294 & 25.5 & 621 & 1,094 & 1,332 & 9.6 & 378 & 128 & 102 & 20.2 & 2,141 & 2,066 & 3,288 & 27,000 & 12.2 \\
\hline 87 & 4,273 & 21.1 & 515 & 903 & 1,866 & 7.1 & 279 & 132 & 95 & 18.7 & 1,987 & 1,784 & 2,819 & 27,302 & 10.3 \\
\hline 88 & 4,574 & 19.1 & 467 & 875 & 2,259 & 6.3 & 246 & 141 & 97 & 18.7 & 1,987 & 1,824 & 2,841 & 29,605 & 9.6 \\
\hline 89 & 4,764 & 20.0 & 487 & 952 & 2,661 & 7.6 & 298 & 201 & 97 & 17.7 & 1,882 & 1,720 & 2,873 & 32,087 & 9.0 \\
\hline 90 & 4,672 & 24.5 & 598 & 1,147 & 3,075 & 7.7 & 304 & 237 & 101 & 17.7 & 1,881 & 1,788 & 3,172 & 33,048 & 9.6 \\
\hline 91 & 4,544 & 25.5 & 620 & 1,156 & 3,099 & 6.9 & 271 & 214 & 104 & 17.9 & 1,895 & 1,856 & 3,226 & 33,351 & 9.7 \\
\hline 92 & 4,320 & 21.0 & 511 & 906 & 3,053 & 6.2 & 242 & 188 & 97 & 18.1 & 1,925 & 1,752 & 2,846 & 31,569 & 9.0 \\
\hline 93 & 4,270 & 17.1 & 416 & 729 & 3,220 & 5.2 & 206 & 168 & 87 & 18.1 & 1,925 & 1,577 & 2,475 & 29,900 & 8.3 \\
\hline 94 & 4,296 & 15.1 & 369 & 650 & 3,395 & 4.6 & 181 & 156 & 81 & 17.7 & 1,880 & 1,426 & 2,232 & 28,973 & 7.7 \\
\hline 95 & 4,306 & 15.4 & 376 & 665 & 3,861 & 4.6 & 180 & 177 & 75 & 17.5 & 1,859 & 1,309 & 2,151 & 31,298 & 6.9 \\
\hline 96 & 4,260 & 18.6 & 453 & 792 & 3,911 & 5.4 & 213 & 211 & 82 & 17.1 & 1,810 & 1,406 & 2,409 & 32,335 & 7.5 \\
\hline 97 & 4,191 & 20.5 & 500 & 860 & 4,147 & 5.5 & 216 & 227 & 87 & 17.6 & 1,872 & 1,532 & 2,619 & 32,472 & 8.1 \\
\hline 98 & 4,152 & 16.9 & 411 & 701 & 4, 208 & 5.3 & 209 & 223 & 83 & 16.7 & 1,777 & 1,387 & 2,311 & 29,393 & 7.9 \\
\hline 99 & 4,226 & 16.8 & 408 & 708 & 4, 208 & 4.1 & 159 & 171 & 81 & 16.2 & 1,804 & 1,308 & 2,186 & 28,063 & 7.8 \\
\hline 2000 & 4, 079 & 23.6 & 567 & 964 & 4,447 & 3.7 & 140 & 166 & 83 & 16.2 & 1,802 & 1,352 & 2,482 & 29,662 & 8.4 \\
\hline 01 & 3,803 & 24.7 & 592 & 938 & 4,709 & 4.6 & 175 & 219 & 80 & 16.2 & 1,803 & 1,293 & 2,450 & 28,161 & 8.7 \\
\hline 02 & 3,595 & 24.2 & 579 & 868 & 4,632 & 4.6 & 173 & 213 & 79 & 15.1 & 1,679 & 1,193 & 2,274 & 27,119 & 8.4 \\
\hline 03 & 3,499 & 26.2 & 629 & 917 & 4,567 & 4.0 & 151 & 184 & 80 & 14.8 & 1,642 & 1,178 & 2,279 & 27,161 & 8.4 \\
\hline 04 & 3,278 & 28.5 & 682 & 933 & 4,846 & 5.5 & 207 & 267 & 77 & 14.4 & 1,604 & 1,117 & 2,317 & 28,114 & 8.2 \\
\hline 05 & 3,038 & 38.1 & 913 & 1,157 & 4,773 & 6.8 & 256 & 325 & 79 & - & - & - & - & - & - \\
\hline
\end{tabular}

重油価格：日本経済新聞社調べ (年ベース)

石炭価格：「石油資料月報」（石油連盟）（年ベース）

電力料金：「エネルギー・経済統計要覧 2006」(省エネルギーセンター） (年ベース)

*電力料金のみ 2005 年度データなし

するとともに, 中長期計画の提出義務やエネルギー管理 士の選任義務が課せられた。一本化初の定期報告書のメ 切が，昨年は $\mathrm{CO}_{2}$ 量報告なしで 9 月末であったが，今 年からは $\mathrm{CO}_{2}$ 量（2006 年度実績）も一緒で 6 月末とな っている。

\section{(2) 荷主に係る措置}

自らの事業活動に伴って委託あるいは自ら輸送してい る貨物の年度輸送量が， 3,000 万トン・キロ以上の事業 者（全業種対象）を特定荷主として指定した。特定荷主
は，2006 年 4 月 1 日から自社輸送量（トン・キロ）を 把握して，企業ベースで定期報告するとともに，実施可 能な取組を選定し，計画書も提出しなければならない。 一本化初の定期報告書の 切が今年は 9 月末であるが, 来年からは 6 月末となる。

なお，詳細については，以下の資源エネルギー庁ホーム ページをご参照願う。

(http://www.enecho.meti.go.jp/policy/saveenergy/ save $02 . \mathrm{htm}$ ) 
(百万t- $\mathrm{CO}_{2}$ )

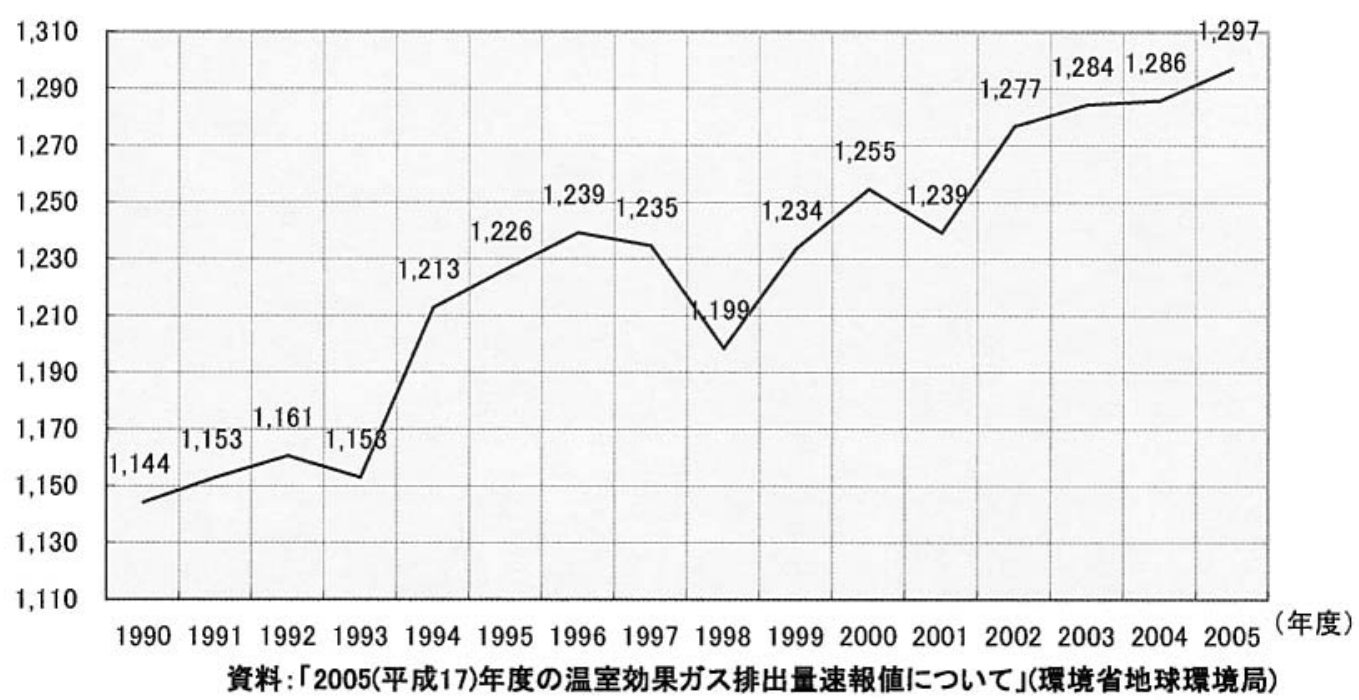

図 13 わが国の $\mathrm{CO}_{2}$ 排出量の推移

表 10 部門別 $\mathrm{CO}_{2}$ 排出量の推移

\begin{tabular}{|c|c|c|c|c|c|c|c|c|}
\hline & \multicolumn{6}{|c|}{$\mathrm{CO}_{2}$ 排出量（百万 t） } & \multicolumn{2}{|c|}{ 2005年度＼cjkstart増減\% } \\
\hline & \multicolumn{2}{|c|}{$\begin{array}{l}\text { (1) } 1990 \text { 年度 } \\
\text { 構成比 \% }\end{array}$} & \multicolumn{2}{|c|}{$\begin{array}{l}\text { (2)2004年度 } \\
\text { 構成比\% }\end{array}$} & \multicolumn{2}{|c|}{$\begin{array}{r}\text { (3)2005年度 (環境省速報) } \\
\text { 構成比\% }\end{array}$} & $\begin{array}{c}\text { 1990年度比 } \\
\text { (3)/1) }\end{array}$ & $\begin{array}{c}\text { 2004年度比 } \\
\text { (3)/2 }\end{array}$ \\
\hline エネルギー転換部門 & 68 & 6.0 & 75 & 5.8 & 74 & 5.7 & 119.7 & 101.5 \\
\hline 産業部門 & 482 & 42.1 & 466 & 36.2 & 466 & 36.0 & 96.8 & 100.2 \\
\hline 業務部門 & 164 & 14.4 & 227 & 17.6 & 234 & 18.0 & 142.2 & 103.1 \\
\hline 家庭部門 & 127 & 11.1 & 168 & 13.0 & 175 & 13.5 & 137.4 & 104.5 \\
\hline 運輸部門 & 217 & 19.0 & 262 & 20.3 & 257 & 19.8 & 118.1 & 98.2 \\
\hline 工業プロセス & 62 & 5.4 & 53 & 4.1 & 54 & 4.1 & 86.3 & 101.1 \\
\hline 廃棄物 & 23 & 2.0 & 36 & 2.8 & 37 & 2.8 & 161.2 & 101.1 \\
\hline 合計 & 1,144 & 100.0 & 1,286 & 100.0 & 1,297 & 100.0 & 113.3 & 100.8 \\
\hline
\end{tabular}

工業プロセス：コークスやセメントなど燃料以外で排出するプロセス由来の $\mathrm{CO}_{2}$

廃育物：焼却ほか

資料：(独)国立環境研究所 地球環境研究センター 温室効果ガスインベントリオフィス（GIO）

http : //www-gio.nies.go.jp/aboutghg/nir/2006/NIR_JPN_2006v2_J_060830_v8.8.pdf

資料：「2005（平成 17）年度の温室効果ガス排出量速報值について」（環境省地球環境局）

http : //www.env.go.jp/press/file_view.php?serial=8616\&hou_id $=7603$

\section{2 改正地球温暖化対策推進法}

京都議定書が採択された翌年の 1998 年 10 月に，国，地 方公共団体，事業者，国民が一体となって地球温暖化対策 に取組むための枠組を定めた地球温暖化対策推進法が成立 した。その後, 京都議定書の的確かつ円滑な実施を確保す るため, 2002 年 6 月に京都議定書目標達成計画の策定等 を定めた改正法が公布された。このうち, 京都議定書目標 達成計画は 2005 年 4 月に策定され, 今年はその見直しが 予定されている。更に，2005 年 6 月に地球温暖化対策推
進本部の掌握の追加や，温室効果ガスの排出量の報告等を 定めた改正法が公布され，2006 年 4 月に施行された。

特に，温室効果ガスの排出量に関する算定・報告・公表 制度について簡単に紹介すると，年間 3,000 トン $\left(\mathrm{CO}_{2}\right.$ 換 算）以上の温室効果ガス（6 種類）を排出する者（特定排 出者）は，各ガスの排出量について $\mathrm{CO}_{2}$ 排出係数を用い て算定し，その結果を国に報告しなければならず，国はそ のデータを集計し公表する事とした。第 1 回定期報告書 （2006 年度実績）のみ切は今年の 6 月末であるが，特定荷 

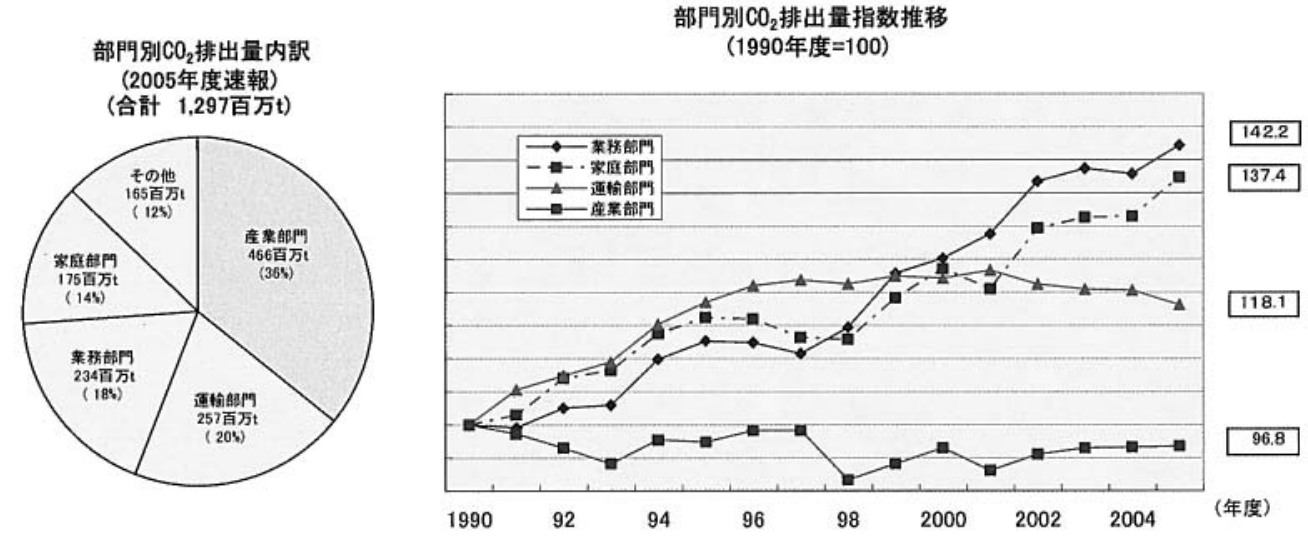

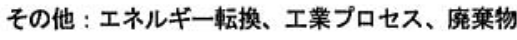

\section{資料：(独）国立賟境研究所 地球環境研究センター 2005 年度は環境省速報値}

図 14 部門別 $\mathrm{CO}_{2}$ 排出量内訳および排出量指数推移

主は 9 月末となっている（来年からは 6 月末）。 なお, 詳細については, 以下の環境省ホームページをご
参照願う。

(http://www.env.go.jp/earth/ondanka/domestic.html) 